\title{
COMMERCIAL VIABILITY OF FOREST PLANTATIONS IN SRI LANKA
}

\author{
A C M Hanas and H B Kotagama \\ Department of Agricultural Economics, \\ University of Peradeniya.
}

The Forestry Sector Master Plan (FSMP) approved by the Government of Sri Lanka has identilied the need for commercialised state owned forest plantations. This study examines commercial viability of single species forest plantations (Albizia, Eucalyptus, Mahogany Pines and Teak) for Timber (saw log and non-sow log) production and Pines plantations for resin lapping and subsequent timber production.

Financial analysis aids planning of investment, financing and assessing business operations. Decisions on investments and financing a business primarily depends on financial profitability. In financial analysis benefits and costs realised over time are discounted using market lending interest rate to compare benefit and cost in present values. A most common decision criterion that is used is the Internal Rate of Return (IRR).

Silvicultural data were based on plantation management plans of the Forest Department and price data were based on estimattes of stumpage values (base case) and past model market price of timber. The opportunity cost of capital was considered as $14 \%$ and the environmental benefits of forest plantations, which were non-financial, have been considered to determine public incentives required for forestry.

The results indicate on the base case and the sensitivity analysis for yield (10\% increase yicld) and cost (20\% reduction of cost) that only teak plantations are financially viable. Pines resin tapping from new plantations is not financially viable. Albizia, Eucalyptus, Pines and Teak harvested for timber is financially viable. if subsidised to compensate environmental benefits. It is also found that forest plantations are not financially viable on value at site (stumpage value) but financially viable at processed timber sales.

This study indicates that indiscreet commercialisation of state owned plantations is not possible. However some forest plantations could be commercialised if a subsidy equivalent to environmentally benefit is provided.

Procedings of the Fourth Anmal Forestry and Environment Symposium 1998 of the Department of Forestry and Environmental Scionce, University of Sri Iayewardene'pura. Sri Lanka 